\title{
China venture market overview
}

\author{
Marina S. Reshetnikova \\ Peoples' Friendship University of Russia (RUDN University) \\ 6 Miklukho-Maklaya St., Moscow, 117198, Russian Federation
}

\begin{abstract}
Today the Chinese economy has rapidly begun the transition to a new stage of development. Its basis is high-tech production and national breakthrough technologies. This process happens due to the transformation of the government strategy in the direction of scaling up innovation through the inclusion of small and medium enterprises. China has been able to raise venture investments for its new development plan. However, since 2016, the rapid growth of the Chinese venture market has raised many concerns. The purpose of the study was to analyze and assess the current state of China's venture capital market. The research proved that, despite signs of overheating, it is still premature to talk about the formation of a "bubble" in the Chinese venture market. The article concludes with a discussion that China is transforming itself again and that the next wave of innovation and private entrepreneurship will be the wave of the future, with substantial global consequences.
\end{abstract}

Keywords: venture capital, innovative entrepreneurship, R \& D, China, start-up

\section{Introduction}

Today, Chinese NIS is one of the most significant innovation ecosystems in the world. Chinese innovations, especially in the field of the Internet, leave a global mark, and society is already more digitalized than in the West. Chinese giants such as Baidu, Alibaba, Tencent, and Xiaomi are gradually conquering the world and are among the ten largest Internet and technology companies.

Since 2014, the state of the Chinese economy has been causing more and more concern. The government successfully suppressed the turbulence in the stock market in 2015, but at the same time, the crisis can spread to the venture capital market. Besides, this will have a catastrophic effect not only on the innovation sector but also on the entire Chinese economy, which at the moment is very dependent on innovation.

The purpose of this article was to analyze the current state of the venture capital market in China and identify the reasons for its avalanche-like growth. This analysis will provide an evidence-based answer to the question: are there real concerns about crisis signs in China's innovation sector? 


\section{Literature review}

Today, companies looking to the future should focus not only on Silicon Valley as a source of innovation but also on China. Since the reforms that took place about four decades ago, China has mostly been considered a country that imitates (Augier et al., 2016). The paradox is that China lagged behind Western Europe in the field of technological innovation, despite the accumulated knowledge and record inventions in the past. The most frequently cited explanations for this situation include weak domestic markets, as well as a lack of property rights as an incentive for entrepreneurs. This paradox, combined with the long Chinese history of totalitarian control and power, has damaged freedom, creativity, and the desire to create new enterprises that embody technological and economic development (Ahlstrom, 2014). Despite today's difficulties, China focuses on human capital, innovation, and entrepreneurship (Li et al., 2017) as the main factors for economic growth. This strategy is facilitated by low labour costs and high capital investments. China needs to increase GDP by $2-3 \%$ directly from innovation and new enterprises in order to maintain annual GDP growth of 5.5-6.5\% in the next decade (Woetzel et al., 2015). This forecast explains the decision of the Chinese government to promote Mass Entrepreneurship and Innovation for All policy and support a strategy to reduce the contradictions between traditional government practices and the urgent need to promote innovation and new ventures. All of the above explains the fact that China's position in global technology leadership remains an open and hotly debated issue (Zhou et al., 2016).

\section{Methods}

The methodological basis of the research was various combinations of theoretical analysis based on methods of comparison and classification, methods of media scanning, Delphi, and crowdsourcing. The information base consists of annual reports published by official institutions of China and major consulting companies, articles, and monographs of Chinese and Western economists. The main scientific provisions of this research were developed by the author independently.

\section{Research results and discussion}

The innovative realities of China's NIS are the scaling of hackspaces and business incubators, and the uprise of business angels and venture funds as the sources to finance small and medium enterprises (SMEs).

Among the most significant scientific results of the study, obtained by the author are the following.

1. The author revealed that the decision made by the Chinese State Council to liberalize the domestic financial market set against the backdrop of declining export demand led to a redistribution of consumer savings towards domestic investment and, as a result, the formation of a stock bubble.

By 2014 in China, the growth rate of investment, industrial production, consumption, and retail reached its six-year low. It became apparent that the growth model, based on the alternation of waves of import substitution and export orientation, is close to exhaustion (see Figure 1), mainly since export generated about $50 \%$ of China's GDP (Agten, 2017). In order to prevent the development of crisis 
phenomena, the government decided to replace the falling export demand with domestic consumption, redirect huge consumer savings to finance domestic investments and remove them from the shadows.

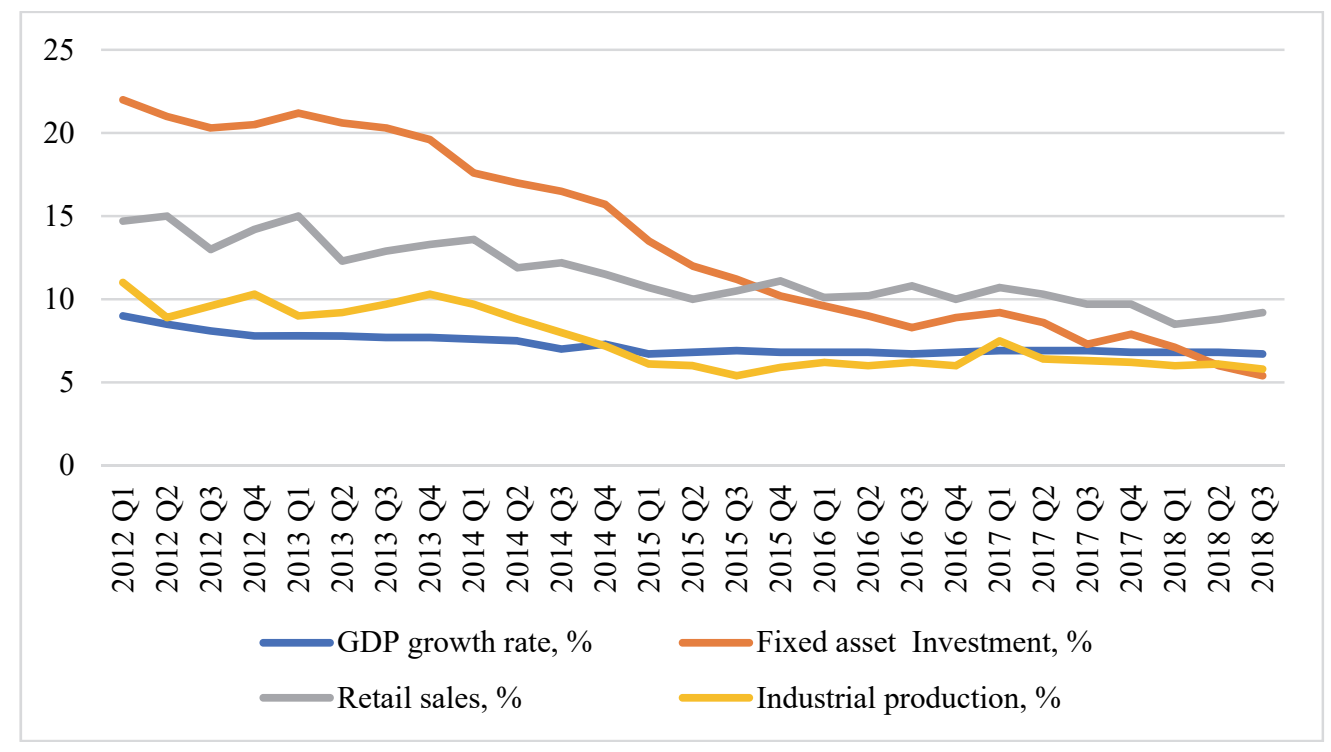

Figure 1. Chinese economy slowdown indicators

Source: compiled by the author based on China - Economic Indicators, 2019.

To this end, China has significantly liberalized the domestic financial system: the stock market, opening personal accounts procedure, trading, and a credit system (Deutch, 2018).

2. The author proved that government policies to curb stock market growth had triggered an avalanche-like increase in private financial investments in venture capital funds.

By 2015, loans worth more than $\$ 20$ trillion were issued in China. Of these, about $\$ 2.8$ trillion were allocated to the population. In mid-2015, the Shanghai Composite Index fell by $28.5 \%$. It became apparent that the "bubble" heated in the stock market began to burst. The government was forced to take unpopular measures to stop the destructive process. Since 2016, short sales of securities to all shareholders were limited. Exceptions were made for investors in the high-tech sector. Investors in China, with colossal (mostly borrowed) funds, were forced to switch to national venture capital funds, where returns are much higher. In the first half of 2016 alone, Chinese investors poured a record $\$ 37.2$ billion in national start-ups, which exceeds this indicator for the entire 2015. As a result, the size of the venture capital market in China in 2016 reached $\$ 338$ billion.

The author argues that in the Chinese realities, new forms of support for innovative SMEs are hackspaces, business incubators, business angels, private venture funds, and major technology companies.

By 2018, China's venture capital market has become a complex multi-step mechanism: with 780 public venture funds with their financial capacity of $\$ 2.3$ billion. Besides, since 2015, private venture funds have been increasingly active, their newly formed capital amounted to $\$ 30$ billion. 
Also, the investment activity of business angels is becoming increasingly visible in the venture capital market in China. This happens due to the growth of the so-called HNWI - individuals with assets of more than \$ 1.6 million. The most significant amount of all venture capital investments, namely more than $50 \%$, is accounted for the development of Internet solutions, IT, and telecommunication technologies.

So, in 2017 only in the high-tech SME sector, 5812 angel transactions were registered, with a total investment of about $\$ 4$ billion disclosed (two times more than in 2015). The most favorable sectors for PE/VC in 2017 were media and entertainment, healthcare, high technology, consumer, and real estate (see Figure 2).

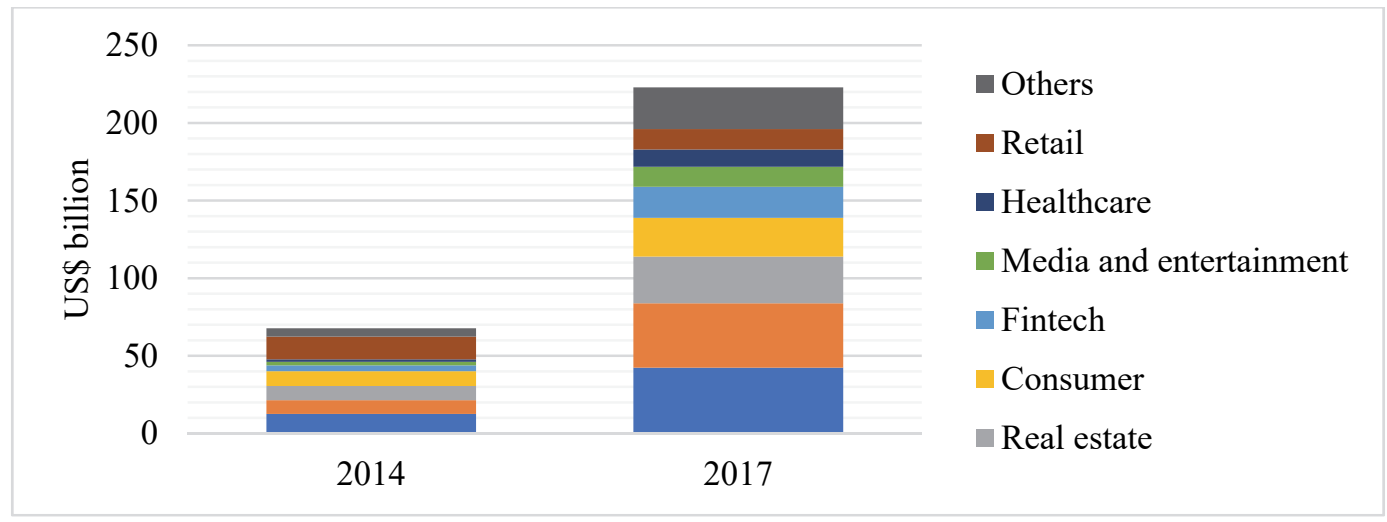

Figure 2. China's venture capital investment reflected in Top 10 main industries

Source: compiled by the author based on ChinaVenture and PwC analysis China Private Equity/Venture Capital Review, 2017.

Here are the realities of China's venture capital market. In 2015 private investment of different sizes and scale came into play. The growth trend of the number and scale of business angels, private venture capital funds, and agencies cannot but worry. Rescue, according to the author, might be hiding in the national characteristics of China's venture capital investments, which are already becoming apparent today.

So, in 2018, in the sector of high-tech SMEs, 5812 transactions with business angels were registered, the total investment amounted to about $\$ 4$ billion (two times more than in 2017).

Today, China has the most sophisticated start-up ecosystem outside the United States. Dynamically developing innovation bases exist in Beijing, Hangzhou, Shanghai, and Shenzhen, indicating the possibility that China will succeed in creating innovative and entrepreneurial opportunities that will become new drivers of economic development (Reshetnikova, 2015).

3. The author identified the features of China's venture capital investments that provoke the risks of warming up the Chinese venture market.

National characteristics of the Chinese venture capital market include not only the scale and dynamics of development but also the distribution of investment by stages of the project's maturity. In China, start-ups in the initial stages are of the most considerable interest among investors (see Figure 3). 


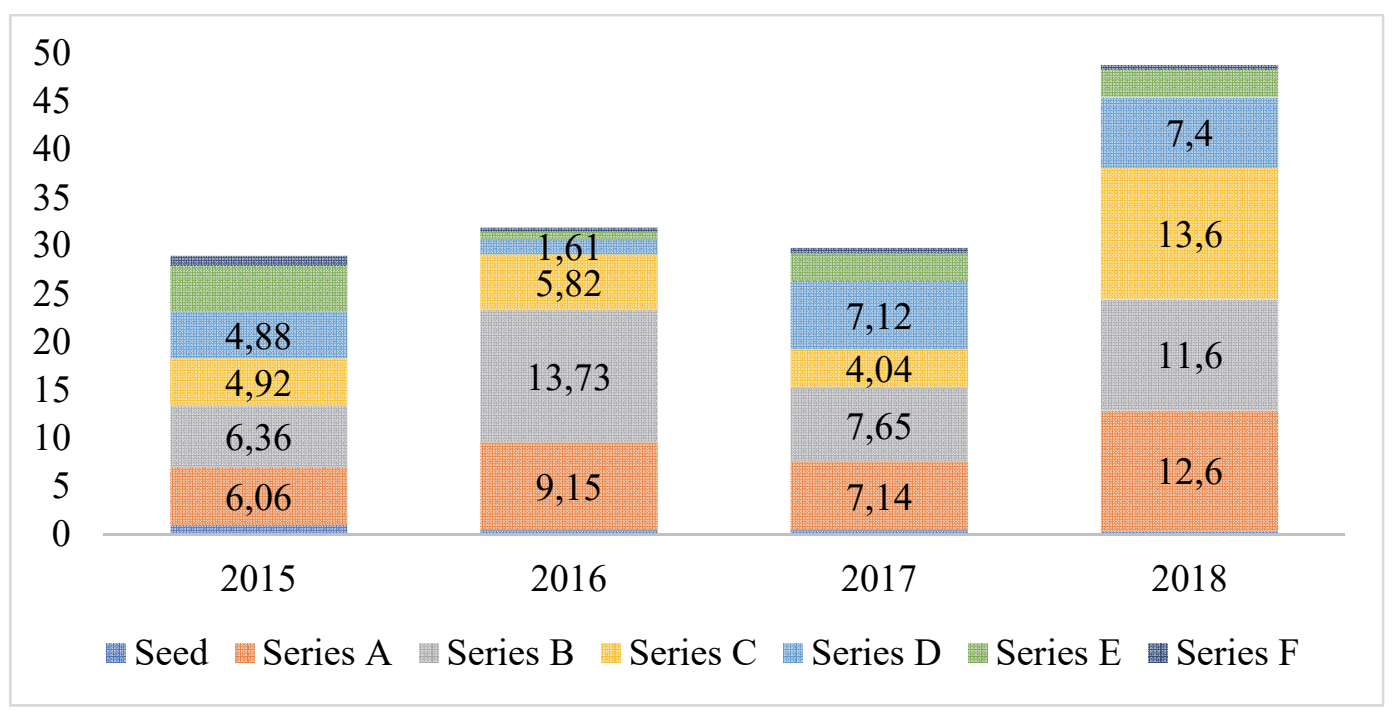

Figure 3. Start-up financing by rounds in China (US \$ billion), 2015-2018

Source: compiled by the author based on ChinaVenture and PwC analysis China Private Equity/Venture Capital Review, 2017; Prequin special report: Asian private equity and venture capital, 2018.

Moreover, this interest is continuously growing. If, in 2014, the number of investment transactions in the early stages was $46 \%$, then in 2018 , according to the disclosed data on the volume of investments, investment in projects at these stages reached 52\%. Moreover, this happens despite the fact that in 2017 globally, there was a decrease in investor interest in the seed and early stages. The average transaction size at all early stages of venture financing has also been growing in China since 2017 (Global Innovation Index, 2018, 2019). According to the author, the main guideline in the strategy of most Chinese investors (public and private foundations, business angel clubs) is non-targeted financing: they want to invest in as many start-ups as possible in the early and seed stages so as not to miss the next unicorn.

The seed investment in China is very high. They range from a few million to tens of millions. Thanks to this, for example, the time needed for a new start-up to rise from an idea to the start of production in Zhongguancun, thanks to its resource base, is only three to six months. In 2017 alone, more than five million new companies were registered in China, and more than 300 thousand of them are engaged in IT. The scale of the high-tech sector of the Chinese economy is striking, and it is the primary beneficiary of avalanche-like venture capital.

The picture would be rosy, if not for one circumstance, identified by the author. Based on the needs of domestic customers, which are less sophisticated than in Western countries, Chinese start-ups make billions of "nothing" and go on IPO. After a successful IPO, they are absorbed by companies such as Baidu or Alibaba. The purpose of the purchase is often very prosaic - to expand skills or eliminate competition. Confirmation for this phenomenon is a significant increase in the number of M\&A transactions in the high-tech sector, which began in 2016. In 2014, these were 851 transactions for $\$ 47.5$ billion and 1,200 transactions in the amount of $\$ 947.5$ billion in 2017 , as well as an increase in the number of unicorns with a total of 55 companies by 2017 (Ahlstrom et al., 2018). 
As a result, investors only increase the volume of financing venture projects. The circle in China's venture capital market has closed. Its current reality: accelerating warm-up and the emergence of new risks.

\section{Discussion}

Since 1978 China has experienced the most significant rise in the economy in comparison with other countries in modern history and the fastest growth in all major economies. According to the World Bank criteria in several decades, China was able to pass the way from a "low-income economy" to a "high-income" country. Unique "Chinese characteristics" sometimes explain this extremely rapid development. Although the combination of global forces driving economic growth is unique in China and provides unique "Chinese characteristics," they can operate throughout the global economy. China's political response to the international financial crisis was much more effective than in other large economies. According to the author, the idea of the Chinese government to redirect the vast savings of consumers to finance innovative domestic companies and projects and bring them out of the shadows was not bad.

The author agrees that today, the volume of venture investments is avalanchelike. Investors invest money earlier than usual, and less time elapses between successive rounds of investment. Unicorns unjustly devour food. However, the situation in the venture capital market cannot but cause concern. According to the author, beating the signal drums is premature. Instead, this situation is more like a "mania to open a business" in response to weaknesses in government actions.

Venture capital is a crucial tool for entrepreneurship and innovation. Chinese venture capital expansion has links to the fast-growing Chinese economy and domestic market since the 1990s. China showed unexpected growth of internal funds and venture investment, but there are risks to getting a mixture of American financing and Chinese corruption. Chinese economic activity growth rate and technical potential are much bigger than in the US and OECD countries (Deutch, 2018). This point of view correlates with the opinion about the importance of separate power and harmony through mistakes, experiments, and diversity while others disagree with this fact and look at different institutions through the prism of encouragement and innovations obstacles (Ahlstrom et al., 2018).

In April 2017, the China Daily surveyed students on venture capital investments. The result is that about $90 \%$ of them wanted to be entrepreneurs. Everybody dreams about startup ideas, and like the fact, it is reflected in educational principles: complete obedience to the leader (senior). Chinese entrepreneurs are more operators than innovators; it is perhaps their main difference from Western more creative colleagues. The government is trying to assess the problems of Chinese entrepreneurship. Taking into account the removal of restrictions on short sales, IPO, foreign investment, and security sales situation does not guarantee a permanent stabilization on the stock market. Venture investment remains very risky, and these measures may lead to a slowdown in their growth.

The author has not considered the scientific cooperation of China with the innovative leaders in this research work, which is a drawback of this article and determines the goals for further study of the Chinese experience in the development of innovative entrepreneurship. 


\section{Conclusion}

For the last 20 years, China has pulled the world forward. Its economic development and innovative breakthrough have become a point of growth in production and investment in the global economy. A unique role in this process belongs to the development of the venture investment market, which began in 2014 . Its unprecedented volumes, and most importantly, the growth rate had no analogues in the world. However, since 2018, there is an opinion that the Chinese economy is turning to a "black swan." According to the author, today, the Chinese venture capital market deals with the phenomenon of overheating. However, the effectiveness with which the Chinese government began to fight it gives hope that, as in 2015, it will be able to prevent the explosion of the "bubble."

\section{References}

Agten, S. (2019). China's innovation, not investments, should worry Europe. EUobserver. Retrieved from https://euobserver.com/opinion/140331 (accessed: 20.01.2019).

Ahlstrom, D., \& Ding, Z. (2014). Entrepreneurship in China: An overview. International Small Business Journal: Researching Entrepreneurship, 32(6), 610-618.

Ahlstrom, D., Yang, X., Wang, L., \& Wu, C. (2018). A global perspective of entrepreneurship and innovation in China. Multinational Business Review, 26(4), 302-318.

Augier, M., Guo, J., \& Rowen, H. (2016). The Needham Puzzle Reconsidered: Organizations, Organizing, and Innovation in China. Management And Organization Review, 12(1), 5-24. doi: 10.1017/mor.2016.5.

China - Economic Indicators. (2019). Retrieved 21 June 2019 from https://tradingeconomics.com/ china/indicators

PwC China. (2017). ChinaVenture and PwC analysis China Private Equity/Venture Capital Review. Retrieved from https://www.pwccn.com/en/private-equity/pe-china-reviewfeb2017.pdf (accessed: 12.08.2019).

Deutch, J. (2018). Is Innovation China's Next Great Leap Forward? Issues, 34(4). Retrieved from https://issues.org/is-innovation-chinas-next-great-leap-forward/ (accessed: 20.08.2019).

Global Innovation Index 2018: Energizing the world with innovation. (2018). Retrieved 10 Decem-

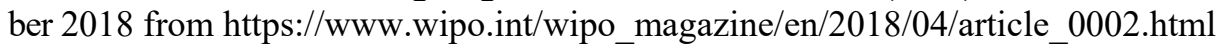

Global Innovation Index 2019: Creating Healthy Lives - The Future of Medical Innovation. (2019). Retrieved 10 September 2019 from https://www.wipo.int/edocs/pubdocs/en/wipo_pub_ gii_2019.pdf

Li, H., Loyalka, P., Rozelle, S., \& Wu, B. (2017). Human Capital and China's Future Growth. Journal of Economic Perspectives, 31(1), 25-48. doi: 10.1257/jep.31.1.25.

Prequin special report: Asian private equity and venture capital. (2018). Retrieved 10 September 2019 from https://docs.preqin.com/reports/Preqin-Special-Report-Asian-Private-EquitySeptember-2018.pdf

Reshetnikova, M.S. (2015). Formirovaniye innovatsionnogo prostranstva na primere evolyutsii pekinskoy eksperimental'noy zony razvitiya vysokikh tekhnologiy [Formation of an innovative space on the example of the Beijing experimental high-tech development zone]. Teoriya i praktika obshchestvennogo razvitiya, (20), 94-97.

Woetzel, J., Chen, Y., Manyika, J., Roth, J., Seong, J., \& Lee, J. (2015). The China Effect on Global Innovation. McKinsey Global Institute, London. Retrieved 26 June 2019 from https://www.mckinsey.com/ /media/mckinsey/business\%20functions/strategy\%20and $\% 20$ corporate $\% 20$ finance/our $\% 20$ insights/chinas $\% 20$ innovation $\% 20$ imperative/the_ch ina_effect_on_global_innovation.ashx

Zhou, Y., Lazonick, W., \& Sun, Y. (2016). China, as an Innovation Nation. Oxford Scholarship Online. doi: 1093/acprof:oso/9780198753568.001.0001. 
Article history:

Received: 11 October 2019

Revised: 08 November 2019

Accepted: 29 November 2019

\title{
For citation:
}

Reshetnikova, M.S. (2019). China venture market overview. RUDN Journal of Economics, 27(4), 753-760. http://dx.doi.org/10.22363/2313-2329-2019-27-4-753-760

\section{Bio note:}

Marina S. Reshetnikova, PhD, Assistant Professor of Department of Economic and Mathematical Modeling, Peoples' Friendship University of Russia (RUDN University). E-mail: reshetnikova-ms@rudn.ru

\section{Научная статья}

\section{Обзор венчурного рынка Китая}

\author{
М.С. Решетникова \\ Российский университет дружбы народов \\ Российская Федерация, 117198, Москва, ул. Миклухо-Маклая, 6
}

Сегодня китайская экономика начала стремительный переход на новый этап развития. Его основой являются высокотехнологичное производство и национальные прорывные технологии. Этот процесс происходит вследствие трансформации государственной стратегии в направлении расширения инноваций путем включения малых и средних предприятий. Китай смог привлечь беспрецедентный по своему объему венчурный капитал для осуществления нового плана развития. Тем не менее с 2016 года быстрый рост венчурного рынка Китая вызывает много опасений. Целью исследования было проанализировать и оценить текущее состояние рынка венчурного капитала в Китае. Исследование показало, что, несмотря на признаки «перегрева», говорить о формировании «пузыря» на венчурном рынке Китая пока преждевременно. Статья завершается обсуждением того, что Китай снова трансформируется и следующая волна инноваций и частного предпринимательства станет волной будущего, имеющей существенные глобальные последствия.

Ключевые слова: венчурный капитал, инновационное предпринимательство, НИОКР, Китай, стартап

\section{История статьи:}

Дата поступления в редакцию: 11 октября 2019

Дата проверки: 08 ноября 2019

Дата принятия к печати: 29 ноября 2019

\section{Для цитирования:}

Reshetnikova M.S. China venture market overview (Обзор венчурного рынка Китая) // Вестник Российского университета дружбы народов. Серия: Экономика. 2019. Т. 27. № 4. C. 753-760. http://dx.doi.org/10.22363/2313-2329-2019-27-4-753-760

\section{Сведения об авторе:}

Решетникова Марина Сергеевна, кандидат экономических наук, доцент кафедры экономико-математического моделирования, Российский университет дружбы народов. E-mail: reshetnikova-ms@rudn.ru 